\title{
POSTDOC: The Door to the Academic Major Leagues
}

\author{
Hugo A. Barrera Saldaña ${ }^{1,2 *}$ \\ ${ }^{1}$ School of Medicine, Universidad Autónoma de Nuevo León; ${ }^{2}$ Vitagénesis SA. Monterrey, Nuevo Leon, Mexico
}

\section{Academic training}

Educational degrees define the profession with which we decide to contribute to a better society; however, we usually have a more selfish motive: obtaining a university degree which will allow us to demand from society the benefits that we feel entitled to. Hence, the words of John F. Kennedy still resonate to this day: "Ask not what your country can do for you; ask what you can do for your country."

In the postgraduate, the situation goes from having a "generic patent" to that where proportionately to our effort, we obtain a "more personalized patent," either from a professional postgraduate (with a greater theoretical knowledge of a specialty field) or experimental (to learn, discover, or invent). With the study program's extension and the amount of time dedicated to research, its programs were divided into masters and Ph.D. While the first research is conducted without running any great risk in a known field and with the tutor or thesis director in charge of most of the intellectual contributions, in the Ph.D., the field is unknown, the risk to reach objectives is greater, and accomplishing them depends more on the student than the thesis director, contributing enough new knowledge for a couple of scientific publications, making the debut of the new Doctor as a scientific researcher with the right foot.

\section{Life beyond the Ph.D.}

Considerable doctorate programs have spread everywhere, with a quality that leaves much to be desired. In our country, a proof of their deficiencies is the fact that their graduates, if they are lucky, barely reach the candidate level in the National System of Researchers (SNI, by its Spanish acronym, is a branch of our National Council of Science and Technology, which evaluates researchers through committees of peers), failing to reach the promotion to the first level of three which the system scores. For them, in particular, but for every student undertaking the doctorate seeking my advice, what I always recommend is to do the post-doctorate (commonly referred to as postdoc and is equivalent to the immediate step after obtaining the doctorate and before competing at a university for the position of assistant professor, which is the entry door to a university academic career) at an internationally-renowned laboratory.

Hereafter, I share the events that led me to the postdoc and what that meant for my biomedical research career.

\section{Dreaming of being a biomedical researcher}

During my bachelor's degree thesis (Isolating and characterizing human placental nuclei; including their use in assays of in vitro transcription), my advisor, Prof. Francisco J Sanchez, gave me as a gift copies of a review article published in 1975 in the Annual Review of Biochemistry titled "Eukaryotic nuclear RNA polymerases", its author: French professor Pierre Chambon from the Institut de Chimie Biologique de la Faculté de Médicine de la Université Louis Pasteur of Strasburg, France. With this gift came a warning: "From now on,

\footnotetext{
Correspondence:

*Hugo A. Barrera-Saldaña

E-mail: habarrera@gmail.com

Date of reception: 15-10-2020

Date of acceptance: $30-10-2020$

DOI: 10.24875/RMU.M20000049

Available online: $24-12-2020$

Medicina Universitaria. 2020;22(4):145-148 www.medicinauniversitaria.org

作 license (http://creativecommons.org/licenses/by-nc-nd/4.0/).
} 
this article will be your bible", he proclaimed. And it was! I read it repeatedly and diligently to give me an idea of the composition of the transcription apparatus responsible for generating the instructions with which the genes operate the concert of processes that occur in our cells.

By the time I was well into my doctorate research at the University of Texas Health Science Center at Houston (UTHSC-Houston, Biochemistry Department at the MD Anderson Hospital), my doctorate thesis advisor, Professor Grady F. Saunders, advised me not to return to Mexico without a postdoc. Back then, Pierre Chambon was a renowned expert in molecular biology, thanks to his discoveries in higher eukaryotic genes, their structure in exon and intron "mosaics," and their transcription and regulation. I decided to write to him, and we met at the International Congress of Cellular Biology in Berlin in September of 1980. During the interview, I managed to obtain a place in his laboratory two years later as a postdoc.

\section{The kingdom of Pierre}

In 1983, in Strasburg, encountering for the first time Professor Chambon, I said hello Professor Chambon, almost reverently, and he replied: call me by my first name simply. He explained, "we have two lines of research on transcription which depend on me: the adenovirus model, which I shared with one of my collaborators, and the SV40, under my direct tutelage". I chose the latter; I then found out that we were 34 postdocs: one French and the rest from all corners of the world, myself being the only one from Latin America.

As a professor, Pierre was exceptional, a man of great authority, pasionate about his work, and with complete knowledge of the world of eukaryotic gene transcription. He expected a lot from us. He did not accept excuses during seminars. Each week, he would send a secretary with photocopies of the latest publications in our field, and the copies came with handwritten annotations from Pierre himself for us to read to be updated. There was a lot of work each week. Thus, some ended up quitting, not being able to cope with the pressure from Pierre.

However, the postdoc was not only science and learning but also another way of practicing it, different from the already successful way I learned in the US. Pierre's laboratory was highly efficient, and the competition only stimulated us further.
His laboratory gave life to an institute organized to be without a doubt the best in the world since it possessed supporting central laboratories (core facilities) where one could go for help from expert technicians to assist us with additional research and characterization tools to advance in our projects.

Luckily for me, my work lifted off quickly and led to several publications in widely renowned journals, including the publications which revealed the role of GC boxes of the gene promoter of the SV40 virus as a key element of the potency of eukaryotic gene transcription. This discovery, along with those of the TATA box, which dictates where transcription begins, and that of the enhancer, which elevates its potency by hundreds of times, are seminal contributions to the study of eukaryotic genes that came out of Pierre's laboratory.

\section{Only when you dream big will you gain enough momentum to reach a place in science history}

As a result of my experience in France, when young researchers arrive at my laboratory to do their master's degrees, I would tell them - just as I was once told - "Why settle for a master's degree, when you can go after a doctorate?" And to those masters attracted by our doctorate: "Why stop after this grand entry into academia, when there's a world out there where there are more grand entries: the postdoc? Over 50 students of the first ones followed my advice, and around 20 of the second students did as well. Therefore, one of my greatest pride as a professor is having seen my students making the most of a wonderful opportunity, a once in a lifetime opportunity, to do a postdoc and enjoy it's privileges (Fig 1).

\section{An invitation to posgraduates}

Graduates of the science doctorate and graduates from medical careers have access to postdocs, even though the latter prefer scientific research more applied to the clinical areas. In table 1, I try to illustrate this with the routes followed by me in contrast with those followed by my friend and extraordinary medical researcher Alejandro Madrigal, author of the article titled "Present and Future Challenge for the use of Stem Cells in HSCT and Cell Therapy," included in this same issue.

Thereby, I hope this essay fuels the dreams of young students undertaking a postgraduate to dream of a postdoc. 
Table 1. Becoming a biomedical researcher versus a medical researcher

\begin{tabular}{|c|c|c|}
\hline Degree/Area & THE ROUTE BIOMEDICINE (Prof. Hugo Barrera) & THE ROUTE MEDICINE (Prof. Alejandro Madrigal) \\
\hline Bachelor & $\begin{array}{l}\text { Biology. Autonomous University of Nuevo Leon } \\
\text { (UANL by its Spanish acronym). Top of his class } \\
\text { and thesis with an honorable mention (Isolation } \\
\text { and characterization of nuclei). }\end{array}$ & $\begin{array}{l}\text { Physician, Autonomous University of Mexico (UNAM by its } \\
\text { Spanish acronym), honorable mention for having the highest } \\
\text { score in all clinical subjects. }\end{array}$ \\
\hline Specialization & $\begin{array}{l}\text { Science and Technology Commercialization, } \\
\text { UT-Austin graduate (selected as the best student.) } \\
\text { Graduation paper: DNA gypsies, a start-up of } \\
\text { molecular diagnosis). }\end{array}$ & $\begin{array}{l}\text { Internal Medicine, "20 de Noviembre" hospital of ISSSTE. } \\
\text { Honorable mention for performance in clinical rotations. } \\
\text { Specialization in immunohematology and histocompatibility. } \\
\text { Thesis: Gardner syndrome and clinical cases. }\end{array}$ \\
\hline Master & $\begin{array}{l}\text { Biomedical Sciences, UTHSC-Houston. Human } \\
\text { gene cloning (hPL gene). Promoted to Ph.D. }\end{array}$ & $\begin{array}{l}\text { Immunogenetics at Harvard U. Study of genetic differences } \\
\text { of HLA and antitumor response genes. }\end{array}$ \\
\hline Doctorate & $\begin{array}{l}\text { Biomedical Sciences. UTHSC-Houston. } \\
\text { Dissertation: Expression of human placental } \\
\text { lactogen. Declared Distinguished Alumnus. }\end{array}$ & $\begin{array}{l}\text { Immunogenetics. University College London. HLA } \\
\text { recombinants to produce tumor and autoimmune antibodies. } \\
\text { Honorable mention. }\end{array}$ \\
\hline Postdoc & $\begin{array}{l}\text { Genetic regulation. Université Louis Pasteur, } \\
\text { Strasburg. Role of GC boxes of the early promoter } \\
\text { of the SV } 40 \text { virus. }\end{array}$ & $\begin{array}{l}\text { Immunogenetics and cellular therapy at Stanford U. } \\
\text { Genotyping methods of HLA alleles. }\end{array}$ \\
\hline
\end{tabular}

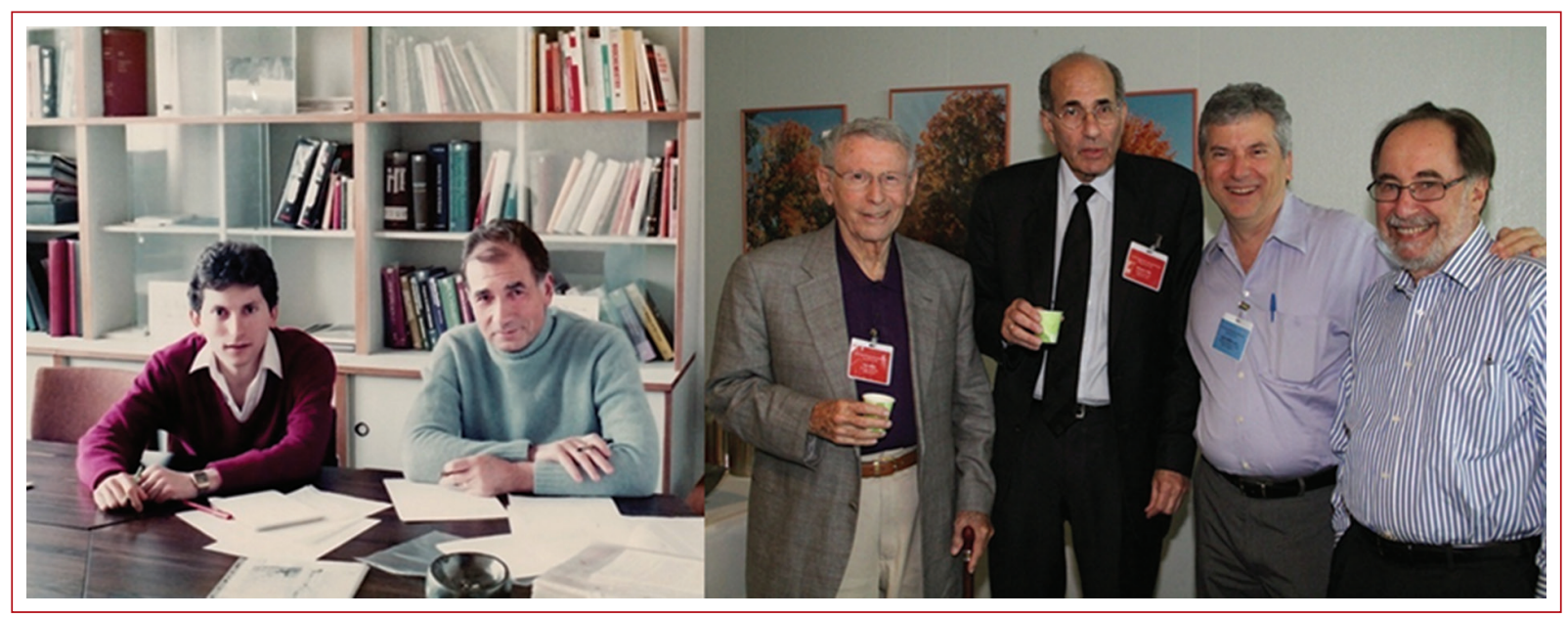

Figure 1. Privileges of a postdoc. Picture on the left Pierre reviewing the manuscript of what became my most important publication during my postdoc. Picture on the right three Nobel prize winners. From left to right Paul Berg (Recombinant DNA, 1980), Richard Axelt(olfactory receptor genes, 2004), the author, and David Baltimore (Reverse Transcriptase, 1975) during a break at the symposium in honor of Pierre Chambon's $80^{\text {th }}$ birthday.

\section{Publications from training as a biomedical researcher*}

a). From the B.Sc thesis:

1. Resendez-Perez D, Barrera-Saldaña HA, Morales-Vallarta MR, Ramirez-Bon E, Leal-Garza $\mathrm{CH}$, Feria-Velazco A, et al. Lowspeed purification of human placental nuclei. Placenta. 1984;5:523-32.

b). From the Ph.D program:

2. Robberson DL, Calabretta B, Barrera-Saldaña HA, Somasundaram T, Lambrou TP, Stubblefield $\mathrm{E}$, et al. Transposable elements in human cells. J Cell Biochem. 1982;6:321.
3. Harper ME, Barrera-Saldaña HA, Saunders GF. Chromosomal localization of the human placental lactogen-growth hormone gene cluster. Am J Hum Genet. 1982;34:227-34.

4. Calabretta B, Robberson DL, Barrera-Saldaña HA, Lambrou TP, Saunders GF. Genome instability in a region of human DNA enriched in Alu repeat sequences. Nature. 1982; 296:219-25.

5. Barrera-Saldaña HA, Robberson DL, Saunders GF. Transcriptional products of the human placental lactogen gene. J Biol Chem. 1982;257:12399-404. 
6. Barrera-Saldaña HA, Seeburg PH, Saunders GF. Two structurally different genes produce the same secreted human placental lactogen hormone. J Biol Chem. 1983;258:3787-93.

7. Robberson DL, CalabrettaB, Barrera-Saldaña HA. Genome rearrangements and extrachromosomal circular DNAs in human cells. In: Robberson DL, Saunders GF, editors. Perspectives on Genes and the Molecular Biology of Cancer. New York: Raven Press; 1983. p. 51-80.

8. Kidd VJ, Barrera-Saldaña HA, Saunders GF. The human growth hormone and placental lactogen gene complex. In: Robberson DL, Saunders GF, editors. Perspectives on Genes and the Molecular Biology of Cancer. New York: Raven Press; 1983. p. 143-67.

9. Saunders GF, Calabretta B, Robberson DL, Barrera-Saldaña HA, Lambrou TP. DNA restriction fragment length polymorphisms in human leukemic leukocytes. In: Research Perspectives in Cytogenetics. Baltimore, MD: University Park Press; 1984. p. 1-16.

c). From the postdoc:

10. Baty D, Barrera-Saldaña HA, Everett RD, Vigneron M, Chambon P. Mutational dissection of the $21 \mathrm{bp}$ repeat region of the SV40 early promoter reveals that it contains overlapping elements of the early-early and late-early promoters. Nucleic Acids Res. 1984;12:915-32.

11. Vigneron $M$, Barrera-Saldaña $H A$, Baty $D$, Everett RE, Chambon P. Effect of the $21 \mathrm{bp}$ repeat upstream element on in vitro transcription from the early and late SV40 promoters. EMBO J. 1984;3:2373-82.

12. Barrera-Saldaña HA, Takahashi $K$, Vigneron $M$, Wildeman A, Davidson I, Chambon P, et al. All six GC-motifs of the SV40 early upstream element contribute to promoter activity in vivo and in vitro. EMBO J. 1985;4:3839-49.

13. Gidoni $D$, Kadonaga T, Barrera-Saldaña HA, Takahashi K, Chambon P, Tjian R. Bidirectional SV40 transcription mediated by tandem Sp1 binding interactions. Science. 1985; 230:511-7.

14. Wildeman A, Zenke M, Schatz C, Takahashi K, Barrera-Saldaña HA, Grundstrom T, et al. Interactions between the SV40 early promoter and cellular proteins. In: Gluzman Y, Harbor CS, editors. Eukaryotic Transcription: The Role of Cis and Trans-acting Elements in Initiation, Current Communications in Molecular Biology. United States: CSH; 1985. p. 19-26. *These guaranteed my direct access to SNI's level 1. 